Article

\title{
MARXISM, FEMINISM, AND EPISTEMOLOGICAL DISSONANCE
}

\author{
ABIGAIL B. BAKAN \\ Head of Department of Gender Studies and Professor of Political \\ Studies. Queen's University. Kingston, Ontario. ${ }^{1}$
}

\begin{abstract}
The analytical relationship between Marxism and feminism has engaged critical scholarship and leftist practice since the time of the foundational contributions of Marx and Engels. Socialist feminist analysis has profoundly advanced contemporary Marxism. However, some strands in Marxist theory and left practice continue to be resistant to feminist contributions. It is this resistance that animates this paper, which is theorized as epistemological dissonance. While not in any way universal, such dissonance is pervasive and suggests an epistemological framing. This is suggested to include four dimensions, regarding: (i) temporality; (ii) idealized masculinities; (iii) specific views of totality in relation to class, race and gender; and (iv) the relationship between activism and the academy. Collectively, these elements maintain and advance not only certain tenets understood as "knowledge", but also generate a kind of problematic left common sense that can inhibit constructive Marxist and socialist feminist investigation.
\end{abstract}

\section{Acknowledgements}

Portions of this paper were presented in papers at Society for Socialist Studies annual conference, May 30-June 2, 2012, Wilfrid Laurier

\footnotetext{
${ }^{1}$ Abigail Bakan is Head of the Department of Gender Studies, and Professor of Political Studies, at Queen's University, in Kingston Ontario. Her publications include Negotiating Citizenship: Migrant Women in Canada and the Global System (with Daiva K. Stasiulis), winner of the 2007 Canadian Women's Studies Association annual book award; and Critical Political Studies: Debates and Dialogues from the Left (coeditor with Eleanor MacDonald). Her articles have appeared in numerous international and Canadian journals including Race and Class, Rethinking Marxism, Social Identities, Atlantis, and Studies in Political Economy. Her current research addresses issues of socialist feminism; the racial contract in Israel/Palestine (with Yasmeen Abu-Laban); and dialogues between Marxism and post-colonialism regarding theorizations of anti-racism (with Enakshi Dua).
} 
University, Waterloo, Ontario, and at the Historical Materialism conference, May 11-13, 2012, York University, Toronto, Ontario and the Marxism and Feminism stream of the Historical Materialism conference, November 8-11, 2012, London, England. The arguments developed here have been substantially advanced through hours of conversation with Paul Kellogg, whose contribution and support for this project I gratefully acknowledge. Thanks are also owed to Alan Sears, Janet Conway, Elaine Coburn, and the anonymous reviewers. Errors rest solely with the author.

\section{Keywords:}

Marxism; feminism; gender; epistemology; socialist-feminism.

\section{Introduction: Framing and Naming the Problem}

The analytical relationship between Marxism and feminism - the latter sometimes referred to in early iterations as 'the woman question' - has engaged critical scholarship and leftist practice since the time of the foundational contributions of Marx and Engels. August Bebel's Woman Under Socialism (1971 [1883]) and Frederick Engels' Origin of the Family, Private Property and the State (1973 [1884]) continue to be considered classic texts of the Marxist canon. The conversation has proven to have considerable longevity, and with good reason. Socialist feminist analysis has profoundly advanced contemporary Marxism, developing our understanding of core concepts and pivotal issues. These include, for example, the role of social reproduction (Ferguson, 1999; Bezanson and Luxton, 2006); domestic labour (Benston, 1969; Hensman, 2011); the relationship between the private and public spheres (Young, 1990); the nature of the working class (Armstrong and Armstrong, 2010 [1993]); and the role of gender and sexuality in shaping state ideology and hegemony (Hennessy, 2000; Kinsman and Gentile, 2010).

However, some strands in Marxist theory, and some currents of left practice inspired by or crediting Marxist analysis, continue to be resistant to feminist contributions. The question that animates this article is, what is the nature of this resistance, and, relatedly why has it proven to be so difficult to address? The resistance takes various forms, from expressions of caution to overt hostility. In activist circles and progressive social movement settings, the manifestations are widespread, and increasingly well documented. Sheila Rowbotham, in Woman's Consciousness, Man's World, written in 1973, summarizes such an experiential moment in the context of the British left: "Men will often admit other women are oppressed but not you. Well it was true in the past but not now, well yes they are in Liverpool but not in London or wherever you live" (Rowbotham, 1973: 38). The continued relevance of Rowbotham's analytical narrative is indicated in findings reported in a recent work, "Deconstructing Militant Manhood", by 
Lara Montesinos Coleman and Serena A. Bassi. These authors, citing the relevance of Rowbotham's earlier contribution, identify patterns of gendered hierarchical performance in contemporary social movement case studies in Britain (Coleman and Bassi, 2011: 211). Feminist theorists have identified similar patterns in other regional settings, though the context varies and issues are articulated in a variety of ways (Conway, 2011)

The resistance of some strands of Marxism to feminism also finds theoretical expression. This can, again, take a number of forms, and is not always explicit. For example, the resistance may include casual dismissal or absence of engagement. The construction of such an "epistemology of ignorance" has been identified regarding the erasure of the contributions of scholars of colour and associated anti-racist scholarship (Mills, 1997; Sullivan and Tuana, 2007). Alternatively, the resistance may involve a type of selective recognition, with a failure to see the feminist contributions of Marxist scholars. Rosa Luxemburg, for example, while commonly recognized for her contributions on issues such as the mass strike or her challenges to reformist practices of the German left in the early 1900s, is rarely noted for her contributions to Marxist feminism and the significance of her close collaboration with Clara Zetkin (see Rich, 1991; Dunayevskaya, 1991). The same pattern can be skewed in the opposite direction, where Marxists are identified as feminists, but their contributions to political economy or socialist theory are neglected. If Rosa Luxemburg has been read as a Marxist and not a feminist, Clara Zetkin's contributions to Marxist theory, for example, have commonly been read as addressing only 'the woman question'. Zetkin's original contributions to concepts of the working class, the united front, or internationalism are often unseen (for a corrective, see John Riddell, 2010). Other Marxist anti-feminist theorizations may be more explicit. Tony Cliff, for example, in Class Struggle and Women's Liberation (1984), offers a particularly sharp formulation.

Feminism sees the basic division in the world as that between men and women....For Marxism, however, the fundamental antagonism in society is that between classes, not sexes.... There can be no compromise between these two views, even though some 'socialist feminists' have in recent years tried to bridge the gap (Cliff, 1984: 7).

How do we explain a notable continued intransigence within the left, specifically the Marxist left, to feminist critique, despite the overwhelming impact of this advance in critical scholarship and its rich lessons for activist and socialist practice? In this article, I argue that this resistance is rooted in a problematic epistemological framing, resulting in a dichotomous relationship between a narrowly constructed 'Marxism' and a similarly constructed 'feminism'. I term this resistance epistemological dissonance, which can be understood as the friction resulting from an encounter with what is perceived as a 
competitive, and discordant, way of knowing; a certain strand of Marxism encounters feminist critique and analysis in such a way. Such an epistemological stance is challenged by a range of alternative approaches that see feminism, or feminisms, as helpful in advancing Marxist theory and practice. These Marxist approaches, however, which strive for a unitary theory to identify capitalism as both an exploitive and an oppressive system, are not the focus of this discussion. Such unitary approaches are considered only insofar as they serve as a counterfactual, to highlight a distinctive but apparently fairly widespread interpretation of Marxism that encounters feminism with epistemological dissonance.

The effort here, then, is simply to identify the elements of what, in toto, would appear to be an epistemological stance that is resistant to feminism in the name of advanced Marxist theory and practice. To this end, I identify four elements, or dimensions, that collectively comprise epistemological parameters in a constructed Marxism that express dissonance when encountered by alternative assumptions and approaches that have tended to ground feminist analysis and critique. These four dimensions are in regard to: (i) temporality; (ii) idealized masculinities; (iii) specific views of totality in relation to class, race and gender; and (iv) the relationship between activism and the academy. Each of these elements serves to reinforce the others. Collectively, they maintain and advance not only certain tenets understood as "knowledge", but also generate a certain left common sense that operates as a kind of cultural closure, excluding other lines of investigation that might threaten to dislodge naturalized assumptions.

In what follows I attempt to explain this epistemological dissonance, and elaborate upon each of the characteristic four dimensions in turn. My aim is neither to revisit earlier debates, nor to attempt to move intransigent Marxist perspectives towards greater accommodation to feminism. Rather, I suggest that naming the dissonance could be helpful in advancing and reviving the dialogue in constructive ways.

\section{Epistemological Dissonance}

Epistemology is defined in the Merriam-Webster dictionary as "the study or a theory of the nature and grounds of knowledge especially with reference to its limits and validity." Explaining the resistance of a current of Marxism to feminism demands consideration of epistemological parameters in part because it is a phenomenon not readily reducible to any single theoretical, methodological or analytical premise. Nor is it defined by any particular current. Indeed, some Marxist feminists who insist on the intersectionality of Marxism and feminism ground their approach in the same Marxist premises that compel others to reject feminism. For example, Raya Dunayevskaya - who, with CLR James originally developed the theory of Russia under Stalin as state capitalist (Rein, S., 2007) - identifies the contemporary women's movement as an extension of the 
emancipatory movement originally theorized as central to Marx's foundational method. She sees this emancipatory urge to have been carried forward particularly by Rosa Luxemburg, and taken up by feminist resistance in the US in the 1960s (Dunayevskaya, 1991). Alternatively, Tony Cliff, also grounding his Marxist method in the theory of state capitalism as applied to the Stalinist period in Russia, and also a student of Rosa Luxemburg, draws the opposite conclusion regarding the women's movement. For Cliff, the 1960s women's liberation movement was a challenge and threat to the movement for working class self-emancipation (Cliff, 1984).

In another example, Lindsey German makes the case for a Marxist analysis against feminism, largely on the basis of feminism's ascribed universal embrace of the role of patriarchy rather than capitalism. However, German draws on the work of Johanna Brenner and Maria Ramas to support this case, developed in Sex, Class and Socialism (German, 1994: 74). The argument is continued in Material Girls, with German noting her debt, again, especially to Brenner (German, 2007: 154-7). But this is a theoretical culde-sac, as Johanna Brenner has herself advanced the case for a unitary Marxist, and socialist, feminism (Brenner, 2000). The case for a Marxist opposition to feminism, in other words, is presented by German in large measure by reliance on the Marxist feminist perspective. Other Marxist feminists, such as Nancy Holmstrom (2011: 254) explicitly root their analyses in Marx's understanding of the centrality of working class selfemancipation - though it is precisely this premise that a Marxist challenge to feminism asserts to preserve.

Grounding the resistance of certain Marxist framings toward feminism in terms of theoretical premises is therefore at the least inconclusive; moreover, it is unsatisfying. A common argument presented among anti-feminist Marxists is that feminism is not intrinsically anti-capitalist. This is certainly a valid assertion. Indeed, the existence, and even dominance, of a bourgeois, or liberal, feminist current that is compatible with capitalism and imperialism is well recognized, not least among socialist and anti-racist feminists (Cudd and Holmstrom, 2011; Eisenstein, 2009; Fraser, 2009). Another argument is that some anti-capitalist feminisms demonstrate the incoherence of the project, moving beyond Marx in ways that embrace autonomism (for example, Federici, 2004). But recognition of multiple feminisms does not support a theoretical rejection of feminism generally, at least from a Marxist perspective. The history of Marxism after Marx is, after all, one of many Marxisms. And even Karl Marx identified the challenge of uniformity, when he famously asserted that if contemporary interpretations of his work constituted "Marxism", he himself was not an advocate (McLellan, 1973: 443). A reductive view of a singular Marxism - identified as bureaucratic, state-centric, etc. - has long been challenged by the most creative Marxists as an inappropriate method to justify dismissal. A similar method - one which first reduces feminism to its most conservative iterations, and then rejects its radical iterations as not really 'feminist' - suggests that something more deeply epistemological is involved in the construction. 
An identification of an epistemological basis to explain the dissonance with which feminism meets a type or strand of Marxism allows us to seek beyond analytical debates that have, in fact, spanned several decades. For the resistant strand of Marxism, these theoretical innovations seem to have generated little relevance. While epistemological parameters are inherently difficult to define precisely, such an exercise is helpful in explaining not only persistent ideas, but common feelings and patterns of exclusion. The epistemological dissonance is not only intellectual, therefore, but also affective (Ahmed, 2004). Marxist feminist Dorothy Smith, for example, a "world-renowned Marxist feminist scholar and activist and a formidable intellect" (Carroll, 2010: 9), in a 2005 publication (originally presented as a 1973 conference paper), notes such an encounter. She describes her experience on the left in Canada:

...[B]ecoming a Marxist has been an enterprise in trying to discover and trying to understand the objective social, economic, and political relations which shape and determine women's oppression in this kind of society.... But trying to become engaged politically in other ways on the 'left' and in relation to Marxists has been an extremely painful and difficult experience. ...How Marxists, whether Social Democrats or Marxist-Leninists, responded to us as feminists does not differ from how we are responded to by the ruling class - the 'upstairs' people (Smith, 2005: 226-7).

The political cultures among even some of the most creative and innovative arenas of Marxist theory and history have proven remarkably resistant to one of the most basic contributions of feminism - recognition of the necessity of involvement of women in traditionally male-dominated discursive spaces. For example, John Riddell noted, in summarizing a series of talks at the Historical Materialism conference in London, UK, in November, 2011, dedicated to his recent translation of the proceedings of the Communist International, that despite numerous notable strengths, "The gender balance among presenters, like that in the field of Communist history studies generally, anachronistically reproduced that of workers' congresses a century ago" (Riddell, 2011). Another example is the Greater Toronto Workers' Assembly (GTWA), formed in October 2009 in response particularly to conditions of economic crisis. The GTWA has raised hopes of providing a refreshing experiment in a new anti-capitalist politics, with a formal commitment to "feminist, queer-positive, and anti-oppression politics," as well as anti-racist politics, as part of its foundational Vision Statement (GTWA, Jan. 2010). However, the organization's early years have been haunted by challenges in attracting and retaining, and advancing the development of, women and visible minorities - challenges readily recognized among activists, though having proven tenaciously difficult to redress (GTWA, July 2010). 
At issue, then, are not merely questions of theoretical analysis, but patterns of practical organizing which have damaging consequences in advancing a unified and effective, radical, socialist alternative to capital and empire. An extreme example of a failure to redress sexist practices has been cited in instances of sexual assault against women in the context of World Social Forum planning and events (Freudenshuss, 2007; Roskos and Willis, 2007). These instances are sufficiently notable that a substantive literature is emerging (see Conway, 2011: 226).

Naming such an epistemological dissonance is not to suggest, however, that a Marxist framework is any more generative of such resistance than other approaches, including liberalism or anarchism (Sullivan, 2004; Sullivan, 2005). Nor is this to suggest that all Marxists, or leftists generally, are collectively implicated. A corollary of this argument is in fact to emphasize that an integrated Marxist feminist analysis can be uniquely helpful in overcoming divisions that are inevitable in movements that emerge in the context of capitalist and imperialist hegemony. Naming an epistemology that meets feminism as dissonant, then, is not only about identifying specific issues in need of debate. It also, and perhaps more significantly, describes the boundaries of what questions are considered to be worthy of asking, a precondition to seriously and constructively entertain such debate. Generic dismissal of feminist critique renders engagement with socialist feminist contributions to Marxism to be uninteresting or unimportant. Feminist analytical or practical concerns can be considered to be the select purview of those with a 'special interest' rather than central to the totalizing and comprehensive frame that renders historical materialism so compelling a method. Epistemological dissonance tends to render central features of the ubiquitous impact of forms of hegemonic regulation, and effective forms of resistance, unknowable within a certain constructed Marxist terminology. Grounded in patterns of gendered practice and experiences, this resistance can be very difficult to challenge from the left. The dissonance is expressed across a spectrum of responses, from an attitude of affective tolerance, where there is verbal acceptance despite patterns of dissonance, to overt rejectionism, where feminist critique and methods are dismissed in both theory and practice. For example, lessons from indigenous, Third World, or anti-racist feminists that have direct bearing on socialist politics commonly fail to enter into the lexicon of what is defined as "Marxist political economy", but are instead seen as issues associated "identity".

I suggest a typology of various distinct elements, or dimensions, that describe the epistemological dissonance of a current of Marxism regarding feminist critique and analysis. Collectively these elements are self-reinforcing, and comprise an epistemological framing of a kind of Marxism that finds feminism to be outside of itself. For this kind of Marxism, feminism is not only unknowable, but suggests lines of inquiry where the questions posed are themselves unaskable. 


\section{Elements of Epistemological Dissonance}

\section{(i) Temporality}

The Marxist tradition is closely associated with specific historical moments, often traced through the writings of individual theorists and events. This temporality register is commonly both nostalgic, and anticipatory. Regarding the nostalgic frame, notable are the writings and contributions of Karl Marx, Frederick Engels, and Vladimir Lenin. The Russian Revolution of 1917 is seen as a formative moment, when the abstract critique of capitalism developed by Marx and Engels moved from theory to practice, and influence mass political events locally and globally. Marxism emerged as a recognized guiding approach for working class revolutionary transformation in a major country. The intense conflict between Leon Trotsky and Joseph Stalin that followed the Russian Revolution divided the movement, and the "lineage" split into various camps by the late 1920s. The Communist International is also seen as pivotal, with those following the emancipatory emphasis of Trotsky focusing on the first four congresses (see Riddell, 2012). There is a sense that there were higher points of success in the past than in the present in terms of revolutionary theory and practice. The nostalgia can be transferred to more modern periods, and can move in moments of both time and space, such as the 1930s in Europe or the 1960s in the US.

Historical memory is constructed, therefore, with a sense of longing, and a desire for repetition. Here the nostalgic and the anticipatory combine. There is a desire to see moment of an idealized history repeated in the future. Revolutionary moments in contemporary analysis, for example, are commonly presented with breathless anticipation that a "February" - referring to a democratic challenge to autocratic rule similar to the February, 1917 moment in the revolution against Tsarist Russia - might just become a new "October" - where a repetition of the successful Russian revolution might again occur. This temporal moment is not only a place in time, but also a geographic space. The specificities of the Russian context are often elided in a universalized sense of the Russian Revolution as an example of radical transformation that can be abstracted to apply to any country or region internationally. Similarly, in this epistemological parameter, other geopolitical specificities can be removed from the field of enquiry. For example, the settler

colonial context of North American capitalism, a central element of feminist anti-racist analyses and some socialist feminist studies, disappears in the assumption of similitudes associated with a universalize, and often European, past (Razack, Smith and Thobani, 2010; Altamirano-Jiménez, 2010).

Other moments of transformation that do not fit the model are, simultaneously, minimized. This contrasts with what can be considered to be feminist view of history, which is commonly not grounded in the work or writings of individuals, or specific singular events, but on collective actions that constitute social "waves". This metaphor is 
associated with narrating the history and development of the women's movement. It is subject to significant critique among "many feminist scholars, particularly over the last decade and a half" who have challenged "its reductive effects on chronicling feminism's history"; but it has nonetheless become "entrenched in feminism's lexicon" (Henry, 2012: 102). It is also seen as problematic in presuming that anti-racist and intersectional feminism is a recent addition to feminist movement, minimizing the role of early contributors such as Sojourner Truth and Harriet Tubman, indigenous women, etc. (see for example Painter, 1996; Mohanty, 2003).

The 'wave' framing (sometimes attributed originally to Julia Kristeva's 1979 essay, "Women's Time"), does, however, contribute to a basic understanding that movements for emancipation change over time. In this sense, the temporality register is very different from the nostalgic/anticipatory one characteristic of some Marxist approaches. Specifically, the wave periodization, with all its limitations, enables a conversation that emphasizes how what appears radical in one context in time and place, can develop conservative impulses that demand challenges in another context (Mann and Huffman, 2005; Brown et al., 2011). The broad elements of this general periodization of the women's movement incorporates the suggestion of: a first wave movement associated with liberal democratic political rights, from the mid-1840s in Europe to women's universal suffrage, (circa 1920); a second wave movement for women's reproductive rights and equality of opportunity in education and employment, associated particularly with the US and the period from 1968 through the 1970s (Lear, 1968); and a third wave associated with intersectionality, that incorporates a broad understanding of gendered identities with race, class, sexual orientation, age, ability and national positioning, often associated with a generational challenge of radical feminist youth to a perceived constrained legacy of the second wave (Walker, 1992; Henry, 2012: 102-105; Gillis et al., 2007).

The notable feature of the waves metaphor, for the purposes of exploring a particular strand of Marxism's epistemological dissonance regarding feminism, is that it is a temporal frame grounded neither in the contributions of ascribed great individuals, nor to universally recognized events or institutions. Moreover, the wave temporal register reconfigures the present, as one that is the product of past struggles but does not romanticize the past. Its appeal is precisely in its unboundedness. This includes both a celebration of third wave 'presentness', as well as recognition of backlash, allowing capacity to look back at headier times of protest. As Astrid Henry notes, the wave metaphor is inherently paradoxical (Henry, 2012: 114). She suggests that it both opens up possibilities and limits them at the same time, as a singular wave model:

makes it difficult to trace out other activist and intellectual precursors - as well as contemporary influences on - its development, including the Civil Rights Movement and critical race studies, the gay and lesbian movement 
and queer studies, and the numerous disciplinary traditions that have shaped the 'interdiscipline' of WGS [Women's and Gender Studies] (Henry, 2012:113).

Regardless of limitations, however, the metaphor has considerable theoretical utility, precisely in its suggestion of flexibility. Ednie Kaeh Garrison has suggested, for example, that a wave frame can be move beyond the 'oceanographic' notion of ebb and flow along a beach, to consider instead 'electromagnetic wavelengths', or radio waves, which travel cyclically (Garrison, 2005: 239; cited in Henry, 2012: 115).

The challenge of temporal framing, of relating history to the present, has certainly been addressed by Marxist scholars (Bensaïd, 2002; Tomba, 2009; Murphy, 2007). However, the wave metaphor can be read as emblematic of particular advances in feminist theorizations of history, historical memory, and periodizations of moments of social change that a tenacious Marxist nostalgia, combined with a desire to repeat historical moments in the future, encounters with epistemological dissonance.

\section{(ii) Idealized Masculinities}

A separate but not unrelated dimension of epistemological dissonance arises in the way a current of Marxism idealizes certain individuals, or ascribed characteristics of idealized individuals who may or may not have any similarity to real historical figures. In the 1970s, when political badges were common among student activists, one commonly sported slogan expressed the norm: "We'll all get along just fine as long as you know I'm Lenin". In a more contemporary and considerably more sophisticated contribution, Coleman and Bassi note certain types of masculinized personalities that are idealized as models of stature and authority in activist left circles, drawing on two case studies in the UK. The authors articulate two ideal types in particular: "Man with Analysis" and "Anarchist Action Man".

The former is described in the context of a Latin America solidarity organization. The hegemonic structure is common, expressing a certain type of masculine performance, "characterized by 'black and white' (sic) reasoning about objective matters, with little room for self-doubt in claims to knowledge, or for reason to be coloured by emotion." Argument was constructed as competition, where one analysis could only be credibly challenged if an alternative Man with Analysis entered the ring (Coleman and Bassi, 2011: 211-212). The authors identify how the hegemonic masculinity of the Man with Analysis led to exclusions of other forms of knowledge, including among those with experience in the Latin American region, women, and men with alternative masculinities who did not want to compete "with the alpha males" (Coleman and Bassi, 2011: 213).

The second masculine personality, Anarchist Action Man, appears to be quite different from Man with Analysis. The outcome of producing patterns of gendered exclusion, however, is similar. The case study here is a direct action planning meeting 
associated with anti-globalization politics.

It is informal, even chaotic, with people sitting around a rickety coffee table on reclaimed sofas, in a colourful room littered with flyers bearing angry slogans. ... However, the impression of chaos is only apparent.... The people in the space all look very similar to each other. They are mostly male, white and under forty....The men, as well as some women with a more masculine gender performance, are all wearing practical, outdoorsy, sometimes military, clothing, much of which is black (Coleman and Bassi, 2011: 215).

It is in this space that Anarachist Action Man takes on specific recognition, to the exclusion of other forms of 'action' that are more inclusive. The outcome of this culture is such that "within the action-planning process, the assumption is that strong, able, masculine bodies will, for example, be 'locking on' to one another to blockade a factory" (Coleman and Bassi, 2011: 217).

While the Man with Analysis is more standardized in Marxist circles than the Anarchist Action Man, a variant that could be suggested that is particularly common in activist circles is what could be termed "Communist Urgent Man". The nostalgia for historic moments of mass conflict runs parallel with a sense of extreme urgency when potential confrontations arise in the present. Communist Urgent Man is perennially impatient. This persona often displays little interest in collective process development, where questions or challenges that are not universally obvious could be addressed. Certain discussions are seen to risk wasting precious time, distracting from the task considered by Communist Urgent Man to be particularly pressing. In fact, those who do not share the same singular priority, or affective sense of immediacy in the task, are considered as potentially obstructionist. Communist Urgent Man understands the moment, and the dire consequences of missing it, even if others fail to perceive the immediacy of the situation and the opportunities it offers.

Notably, moving beyond Coleman and Bassi, who consider these hegemonic masculinities in the context of case studies, in explaining the epistemology of dissonance Man with Analysis, Anarchist Action Man, and Communist Urgent Man, are considered to be gendered personae rather than lived personalities; women can and do take on these personae, and sometimes with added vigour. Moreover, taken as personae rather than personalities, the same individual can move from one to another. Man with Analysis can assume the persona of Communist Urgent Man, though the transition may be unclear to the outside observer. Similarly, Man with Analysis can morph into Anarchist Action Man, shifting from an emphasis on speech and argument to a 'time for action' where conversation is seen as irrelevant. While Anarchist Action Man and Communist Urgent Man often see one another as the subjects of polemic and distrust, these two personae can 
become oddly similar in particular contexts where a singular next step or next action is treated with extreme impatience. However, all of these personae tend to be imbued with a sense of entitlement that is attractive to certain personalities, and are commonly white, heteronormative and driven by a sense of individual competition. Alternatively, those who are the most marginalized by capitalist economic and social relations do not easily perform or embody Man with Analysis, Anarchist Action Man or Communist Urgent Man personae.

In all these idealized personae, epistemological dissonance becomes embedded in organizational patterns where hegemonic masculinities are naturalized. Those informed by, or claiming to advance, a Marxist framework can and do embody these various masculinized ideal types. Feminist challenges may be tolerated, but in a moment of extreme urgency there is little time for reflection or changing course. And in the discursive space of individualized and often competitive "analysis", there is in fact little room for collective processes or common strategic planning. Compressed time and artificially imposed urgency, combined with highly abstract commentary, tend to discourage new relationships of trust to develop; those who feel unsure or unsafe will often draw back from participation, either in organizational planning or in specific activities. Feminist concerns for alteration of patterns of exclusive conversation, planning or process, or other types of masculinities that reject competitive or individualistic models, may be overtly rejected, or only conditionally tolerated. The epistemological dissonance remains unabated and is highly prone to reproduction.

\section{(iii) Totality and Class, Race and Gender}

The strand of Marxism that is epistemologically dissonant in its encounter with feminism commonly frames "class" as its most totalizing category. Indeed a "class analysis" is often presented as the corrective or alternative to a "feminist analysis". Feminism may be rejected or tolerated on grounds that it is a narrow framing, whereas class is considered to name the totality, embracing numerous distinctions but appropriately structured in relation to the productive process.

There are several elements to this construction. The dissonance, at least in part, follows from a temporality, as described above, which is largely nostalgic, where both elite and subaltern classes are considered to be more or less similar over time and place. An understanding of the rule of the capitalist class, for example, in conditions of $21^{\text {st }}$ century globalization, is compared discursively to periods including the Russian Tsarist state of the late nineteenth and early twentieth centuries, or of the United States in the 1930s or 1960 s, without reflection. It is the sameness of these periods, and particularly of the class structures of these various cases, which are assumed, rather than the differences.

"Class" is thus asserted as a totalizing category both in terms of the ruling class 
and the working class, and over time and place. ${ }^{2}$ Some contributions in the 'class versus race' debates (Bakan, 2007) parallel this epistemological framing, where race, like gender, is seen as a narrow or limiting category, whereas class is identified as comprehensive. Within this strand of Marxism, issues of difference within the working class along lines of gender or race, as well as difference more widely, and questions of gendered or racialized privilege, identity or voice, are not central to the emancipatory project. Such questions are either openly rejected as divisive, or tolerated but considered marginal, of interest only as special topics. The particular way in which this assertion of class is epistemologically asserted may see women workers and workers of colour as important, but it is their role as waged workers in empirically defined cases and contexts which is emphasized. Contrary to the abstract and universalized understanding of time and space associated with Marxist history, sex and race are considered to be relevant insofar as they arise as examples in specific conditions. Constructions of gender and racialization are not, therefore, accepted as categories of analysis through which to explain the workings of capitalism and imperialism. The suggestion of the adoption of race and gender as methodological rather than as descriptive tools, encounters this strand of Marxism as epistemologically dissonant.

It is useful to explain this particular element in epistemological dissonance by considering examples of feminist anti-racist contributions that fall outside this particular understanding of "class", as cases of the counterfactual. For example, a classic text in the Marxist cannon, as mentioned earlier, is Frederick Engels' Origin of the Family, Private Property and the State. The subtitle of the book explains the focus: "In Light of the Researches of Lewis H. Morgan" (Engels, 1973). Morgan published a major study of the life and social organization of the Iroquois of northern New York State in 1877, titled Ancient Society (2004). Considered a founder of modern anthropology, Morgan offered an original and detailed account of an indigenous population to the settler audiences of colonial North American and Europe. Against the tide of Victorian morality, Morgan noted particularly that women were not subjugated by patriarchal oppression.

There is, of course, an extensive body of literature considering the contributions of Morgan and Engels in Marxist feminist analysis (Vogel, 1983; Bezanson and Luxton, 2006); this material need not be revisited here. What is salient, however, is that a distinct, and similarly extensive, body of literature written by indigenous feminists falls outside the epistemological frame of the normalized Marxist canon. While these authors identify with longstanding struggles against colonialism, imperialism and capitalism, and many explicitly rely on an historical materialist analysis, the lack of engagement of these contributions from what could be considered 'mainstream' Marxist thinking is striking.

\footnotetext{
${ }^{2}$ This summary is recognized to be a rather crude and incomplete consideration of a Marxist understanding of class. However, a more nuanced discussion, where the category of middle class is addressed, for example, would take us beyond the scope of the current discussion.
} 
In States of Race, for example, the editors pose a radical challenge to capitalism through a focus on the experiences of racialized, immigrant and indigenous women (2010). As the editors note:

The feminist, anti-racist intellectual tradition of which the contributors of this anthology are a part emerges out of a long history. Indigenous women were the first to powerfully critique Canada as a white settler society and to analyze its ongoing colonial practices.... Colonialism has always operated through gender.... Today, with hundreds of 'missing' Indigenous women, women who are presumed murdered, we confront daily what Indigenous scholars mean when they write that sexual violence is how you 'do' colonialism (Razack, Smith and Thobani, 2010: 1-2).

Aboriginal feminists confirm the early observations in Morgan's work (minus the racialized and Eurocentric articulations) (Morgan, 2004). Verna St. Denis, for example, summarizes the case in Joyce Green's edited collection, Making Space for Indigenous Feminism: "[A]boriginal women claim that Aboriginal cultures do not have a history of unequal gender relations; in fact...Aboriginal women occupied positions of authority, autonomy and high status in their communities" (St. Denis, 2007: 37).

Another example is indicated in Leith Mullings' study of race and gender in the making of the US working class (Mullings, 1997). As a feminist, anti-racist anthropologist, she foregrounds her work in questions regarding women's participation in production originally identified in Engels' Origin of the Family, Private Property and the State. She identifies the contributions of Leacock (1981) and Sacks (1979), both of whom extend Engels' formative contribution to feminist anthropology based on contemporary findings. Mullings' series of studies of the US working class notes the formative impacts of racism and sexism in the capitalist accumulation process. She identifies how racism in the postemancipation period meant that African American men were unable to earn a 'family wage', compelling African American married women to participate in the paid labour force in far greater proportions than Euro-American, or white, married women (Mullings, 1997: 45). Mullings is part of a tradition of anti-racist feminism, including those ranging from Angela Davis to bell hooks, which has challenged the claims of white, middle class feminism to universalize a limited racial and gendered view of the American working class family in such a way as to exclude black and minority experiences (Davis, 1983; Guy-Sheftell, 1995). Mullings' adoption of race and gender as methodologically inherent to class analysis indicates an intersectional approach, but it is one that suggests epistemological dissonance in some canonical Marxist readings (see German, 1994: vii).

Another factor that demonstrates this element in the epistemological dissonance is the way that a strand of Marxism tends to conflate the notional totalizing concept of 
class with a particular understanding of 'work'. Here, the contributions of socialist feminist theorists are notably dissonant. There is an extensive body of socialist feminist literature which has addressed the significance of domestic labour and social reproduction in reframing Marx's original analysis of capitalism (Benston, 1969; Vogel, 1983; Floyd, 2009). A notion of the working class that extends beyond the workplace, however, not only addresses the vast amounts of work performed largely by women in the home. It also considers the role of the ruling class in regulating this sphere, as well as the personal and emotional relations between and among individuals. As Rosemary Hennessey has suggested, if we understand "desire as a class act" (Hennessey, 2000: 175), the concept of 'class' itself demands reformulation. Such a reformulation, however, is a source of epistemological dissonance to a Marxism grounded in a very different framing of totality in relation to class, race and gender.

\section{(iv) Activism and the Academy}

The final element in the epistemological dissonance involves the relationship between activism and the university, or what could be called 'the academy'. Marxism has generally emerged outside of mainstream intellectual life in capitalist societies, marginalized by the bourgeois institutions that support advanced research and scholarship. However, the New Left of the 1960s and '70s was deeply rooted in postsecondary student politics, and challenged earlier limitations and boundaries that defined the elite 'ivory tower'. Second wave feminism, which emerged as part of this period of radicalization, has similarly involved an ambivalent relationship to the academy. There is now a substantive experience, associated with an expanding literature, that addresses the role of "Women and Gender Studies" (WGS) in complex interaction with various 'waves' of feminist organizing.

However, WGS and self-identified Marxist currents commonly exist in parallel spaces in the fragmented world of the academy. One element of the distance, arguably, is the epistemological resistance to feminist analysis from a particular strand of Marxism. While WGS programs are not uncommonly the home to socialist feminist theorists, a particular kind of Marxist theorization meets feminist studies in the academy with extreme suspicion. Certainly, the Man with Analysis persona often rests comfortably within the halls of university scholarship as well as in activist circles, but is rarely found in the offices or classrooms of Women and Gender Studies programs. Moreover, where universities have been sites of feminist policy challenges, it is not unusual for selfidentified Marxist professors to be demonstrably resistant, or even antagonistic. This dimension of epistemological dissonance is notable, not merely in its articulation of a defensive posture regarding the language and practice of anti-oppression politics on the university as a site of employment, but also in the challenge of advancing conversations among scholar-activists regarding wider projects. While Marxism and feminism might reasonably be considered natural allies in a university setting threatened by neoliberal and 
corporate policies - led by state, private, administrative and conservative interests - in fact the epistemological dissonance on the part of Marxist scholars when faced with feminist initiatives can be extreme.

The issue of backlash against feminism is significant in considering the university as a site of neoliberal capitalism (Faludi, 1991). This is in part because WGS departments have been particularly vulnerable to cutbacks, and managing defenses of feminist curriculum has depended upon considerable organizational efforts (Piepmeier, 2012). Moreover, universities have generally been reluctant to welcome women and minority scholars as permanent faculty, even in the face of liberal 'equal opportunity' guidelines. The attacks on gains won by women and visible minorities in accessing educational and employment opportunities from which they have been historically excluded have come principally from the state and the right. Conservative challenges to affirmative action, often referred to in Canada as employment equity, have been widespread (Faludi, 1991; Bakan and Kobayashi, 2004).

Unfortunately, the left has been an unreliable ally on this front. Research has indicated how the Ontario New Democratic Party under the leadership of Bob $\mathrm{Rae}^{3}$ stalled in implementing employment equity policy during the five years of its majority government (1990-95) (Bakan and Kobayashi, 2007). An explicit and aggressive backlash against employment equity followed, and became identified as a hallmark of the Conservative government of Mike Harris (Bakan and Kobayashi, 2000). Though an alliance of feminists, anti-racists and labour advocates united in an effort to defend the interests of equity-seeking groups in Ontario (Bakan and Kobayashi, 2003), the role of Marxists in such a movement has been notably uneven. A wing of Marxist and progressive thinking has either stood silent, or campaigned to challenge efforts to sustain employment equity principals (see Whitaker, 2002: 7-8).

One way of understanding this element in the epistemological dissonance is to consider the potential that an alternative approach could offer. Marxism, arguably, has yet to fully explore the tension inherent in the project's relationship between activism and academic institutionalization. Herbert Marcuse, who identified this tension, warned of what he considered the "rampant anti-intellectualism" of New Left radicalism, which he saw posing as a critique of "academicism" (Marcuse, 2007: 176). Others in the Marxist tradition, however, have rejected the limited post-1960s successes of Marxist studies in university curricula, challenging "academic Marxism" as dangerously co-optive (Rees, 1998). Gramsci's concept of the "organic intellectual", while widely cited, remains unclearly situated in the modern university setting in liberal democracies (see McKay, 2000). The concept has been adjusted by Edward Said, who identified the specific responsibility of the 'public intellectual' in linking advanced academic scholarship with social organizing (Said, 1996), but there remains little in terms of more general

\footnotetext{
${ }^{3}$ This same Bob Rae is serving in 2012 as leader of the Federal Liberal Party.
} 
theorization. And Isaac Deutscher exemplified the retreat of the Marxist intellectual absent any form of institutionalized support, as he adopted a metaphor drawn from Leon Trotsky's last "hell-black night" before his assassination at the hands of Stalin's agent. Trotsky, refusing to wear a bulletproof vest, "suggested that it would best be worn by the sentry on duty at the watch tower" (Deutscher, 1970: 401). In different circumstances, Deutscher 'retired' from political engagement to a metaphorical "watch tower", to "watch with detachment and alertness this heaving chaos of a world" (Deutscher, 1984: 57).

Arguably, feminist theorizations on the relationship between academic scholarship and activism have something useful to offer Marxists in this regard. Alison Piepmeier, for example, challenges the construction of a "besiegement" narrative in Women's and Gender Studies programs. She unpacks the emergence of a generational investment in intellectual claims, that serves to alienate young scholars and activists and meets new intellectual advances with a sense of extreme threat (Piepmeier, 2012: 127-8). Martha McCaughey addresses the mythologization of "community" in WGS programs, and attempts to explain its various meanings within and beyond the walls of the university setting (McCaughey, 2012). The point here is not to implore the construction of a healthy dialogue between Marxists and feminist scholars in the academy; rather it is to draw attention to the epistemological dissonance that renders such a consistent dialogue nearly unimaginable. The challenge of even finding a common entry point among activists and scholars, arguably addressing very similar relational challenges, speaks to the epistemological dissonance with which the feminist encounter is met by a certain 'type' of Marxism. Put differently, the Man with Analysis has little interest in WGS programs, discourse, or feminist analysis; and Communist Urgent Man, well, has very little time.

\section{Conclusion: Reclaiming Marxism and Feminism}

The aim in the preceding discussion has been a modest one, simply to name a palpable resistance to feminism identifiable in recurrent locations of Marxist theory and practice as deeply grounded, suggesting epistemological parameters. Epistemological dissonance is apparently widespread, at least within the framework of the English speaking Euro-American left, and has tended to reproduce itself across geographic, ideological and generational spaces. This is not to suggest that it is, however, merely or only epistemological, as there are certainly political, embodied, and varying degrees of this resistance. Indeed some of us have lived in and with ambivalences regarding the relationship between Marxism and feminism for sustained periods. I suggest naming this phenomenon epistemological dissonance. To be clear, this is not an issue reducible to particular theoretical positions or group practices; it is not merely about "debates". Rather, epistemological dissonance is expressed intellectually and affectively to shape historic, 
present and future questions pertaining to feminist analysis - shaping what may or may not be considered relevant for serious scholarly or strategic enquiry.

It is important to stress, further, that this is not an argument regarding Marxism per se, but only a particular, admittedly ill-defined, strand of Marxism, a Marxism that does not know its own name. There is some cost to this dissonant encounter. Indeed, arguably, the voices of indigenous feminists provide the most enduring appeal for a different way of knowing, one that begins with an intersectional analysis that incorporates feminism, anti-racism, and historical materialism. The same indigenous women, men and children who were the objects of study for Lewis Henry Morgan, and in turn Marx and Engels, have come to claim a place as subjects of their own history, as well as their present and future (Mann, 2011).

Evidence suggests then, that the epistemological resistance of a specific wing of Marxist theory and practice has shared space on the left with radical actors, not least Marxist radical actors, deeply influenced by feminism. The epistemological dissonance therefore, perhaps, indicates a positive friction, and the possibility of a creative dialectic and constructive movement towards a better world. Perhaps, then, a better left is possible.

\section{References}

Ahmed, Sarah (2004). The Cultural Politics of Emotion. London: Routledge.

Altamarino-Jiménez, Isabel (2010). "Indigenous Women, Nationalism, Feminism”, in Sherene Razack, Malinda Smith and Sunera Thobani (eds.) (2010): 111-126, in States of Race: Critical Race Feminism for the $21^{\text {st }}$ Century. Toronto: Between the Lines.

Armstrong, Pat and Hugh Armstrong (2010 [1993]). The Double Ghetto: Canadian Women and their Segregated Work. $3^{\text {rd }}$ edition. Canada: Oxford University Press.

Bakan, Abigail B. (2007). "Marxism and Anti-racism: Rethinking the Politics of Difference", Rethinking Marxism, vol. 20, no. 2:238-256.

Bakan, Abigail B. and Audrey Kobayashi (2000). Employment Equity Policy in Canada: An Interprovincial Comparison. Ottawa: Status of Women Canada.

Bakan, Abigail B. and Audrey Kobayashi (2003). "Ontario: Lessons of the Rise and Fall of Employment Equity Legislation from the Perspective of Rights Advocacy", Canadian Race Relations Foundation Reports (March): 35-77. 
Bakan, Abigail B. and Audrey Kobayashi (2004). "Backlash Against Employment Equity: The British Columbia Experience”, Atlantis: A Women's Studies Journal, vol. 29, no. 1 (Fall): 61-70.

Bensaïd, Daniel (2002). Marx for Our Times: Adventures and Misadventures of a Critique, trans. Gregory Eliott. London: Verso.

Benston, Margaret (1969). “The Political Economy of Women's Liberation,” Monthly Review, vol. 21, no. 7 (December).

Bezanson, Kate and Meg Luxton, eds. (2006). Social Reproduction: Feminist Political Economy Challenges Neo-Liberalism. Montreal: McGill-Queen’s University Press.

Bebel, August (1971 [1883]). Woman Under Socialism, trans. Daniel de Leon. New York: Schocken Books.

Bezanson, Kate and Meg Luxton (2006). Social Reproduction: Feminist Political Economy Challenges Neo-liberalism. Montreal: McGill-Queen's University Press.

Brenner, Johanna (2000). Women and the Politics of Class. New York: Monthly Review Press.

Brown, Susan, et al. (2011). Not Drowning but Waving: Women, Feminism, and the Liberal Arts. Edmonton: University of Alberta Press.

Carroll, William K. (2010). “You Are Here': Interview with Dorothy E. Smith”, Socialist Studies, vol. 6, no. 2: 9-37.

Cliff, Tony (1984). Class Struggle and Women's Liberation: 1840 to the Present Day. London: Bookmarks.

Coleman, Lara Montesinos and Serena A. Bassi (2011). "Deconstructing Militant Manhood: Masculinities in the Disciplining of (Anti-) Globalization Politics", International Feminist Journal of Politics, vol. 13, no. 2: 204-224.

Conway, Janet (2011). “Analysing Hegemonic Masculinities in the Anti-Globalization Movement(s)", International Feminist Journal of Politics, vol. 13, no. 2: 225-230. 
Cudd, Ann E. and Nancy Holmstrom (2011). Capitalism For and Against: A Feminist Debate. Cambridge, UK: Cambridge University Press.

Davis, Angela Y. (1983). Women, Race and Class. New York: Random House.

Deutscher, Isaac (1970). The Prophet Outcast: Trotsky, 1929-40. Random House, 1970.

Deutscher, Isaac (1984). Marxism, Wars, and Revolutions: Essays from Four Decades, ed. Tamara Deutscher. London: Verso.

Dunayevskaya, Raya (1991). Rosa Luxemburg, Women's Liberation, and Marx's Philosophy of Revolution, $2^{\text {nd }}$ ed. Chicago: University of Illinois.

Eistenstein, Hester (2009). Feminism Seduced: How Global Elites Use Women's Labor and Ideas to Exploit the World. Boulder, Colorado: Paradigm.

Engels, Frederick (1973 [1884]). Origin of the Family, Private Property and the State. New York: International Publishers.

Faludi, Susan (1991). Backlash: The Undeclared War Against American Women. New York: Crown Publishers.

Federici, Silvia (2004). Caliban and the Witch: Women, the Body and Primitive Accumulation. Brooklyn, N.Y.: Autonomedia.

Ferguson, Susan (1999). "Building on the Strengths of the Socialist Feminist Tradition", Critical Sociology, vol. 25, no. 1: 1-15.

Floyd, Kevin (2009). The Reification of Desire: Toward a Queer Marxism, Minneapolis: University of Minnesota Press.

Fraser, Nancy (2009). "Feminism, Capitalism and the Cunning of History". New Left Review, no. 56 (March-April): 97-117.

Freudenschuss, M. (2007.)'Social Fora: Representing Resistance and Alternatives? Critique and Alternative Interpretation from a Feminist Perspective', Journal of International Women's Studies, vol. 8, no. 3: 37-48. 
Garrison, Ednie Kaeh (2005). “Are We on a Wavelength Yet? On Feminist Oceanography, Radios, and Third Wave Feminism", in Jo Reger (ed.), Different Wavelengths: Studies of the Contemporary Women's Movement: 237-256. New York: Routledge.

German, Lindsay (1989). Sex, Class and Socialism. London: Bookmarks.

German, Lindsay (2004). Sex, Class and Socialism, second edition. London: Bookmarks.

German, Lindsay (2007). Material Girls: Women, Men and Work. London: Bookmarks.

Gillis, Stacy, Gillian Howie and Rebecca Munford (eds.) (2007). Third Wave Feminism: A Critical Exploration. New York: Palgrave MacMillan.

Greater Toronto Workers' Assembly (GTWA) (Jan., 2010). "Vision Statement". http://www.workersassembly.ca/vision

Greater Toronto Workers' Assembly (GTWA) (July, 2010). “Discrimination and Harassment Policy". http://www.workersassembly.ca/vision

Guy-Sheftall, Beverly (ed.) (1995). Words of Fire: An Anthology of African-American Feminist Thought. New York: The New York Press.

Hensman, Rohini (2011). "Revisiting the Domestic-Labour Debate: An Indian Perspective", Historical Materialism, vol. 19, no. 3: 3-28.

Henry, Astrid (2012). "Waves", in Catherine M. Orr, Ann Braithwaite and Diane Lichtenstein, (eds.), Rethinking Women's and Gender Studies: 102-118. New York: Routledge.

Holmstrom, Nancy (2011). "Against Capitalism as Theory and as Reality", in Ann E. Cudd and Nancy Holmstrom, Capitalism For and Against: A Feminist Debate. Cambridge, UK: Cambridge University Press.

Kinsman, Gary and Patrizia Gentile (2010). The Canadian War on Queers: National Security as Sexual Regulation. Vancouver, Canada: UBC Press.

Kristeva, Julia (1979). “Women's Time”, trans. Alice Jardine and Harry Blake, in The Feminist Reader: Essays in Gender and the Politics of Literary Criticism, Catherine Belsey and Jane Moore (eds.): 197-217. Basinstoke: Macmillan, 1989. 
Leacock, Eleanor (1981). Myths of Male Dominance: Collected Articles on Women CrossCulturally. New York: Monthly Review Press.

Lear, Marsha W. (1968). "The Second Feminist Wave", New York Times Magazine, March 10.

Luxton, Meg (2006) "Feminist Political Economy in Canada and the Politics of Social Reproduction.” In Bezanson, Kate and Luxton, Meg, eds. Social Reproduction: Feminist Political Economy Challenges Neo-liberalism: 11-44. Montreal: Queen's University Press.

Mann, Barbara Alice (2011). Iroquoian Women: The Gantowisas. New York: Peter Lang.

Mann, Susan Archer, and Douglas J. Huffman (2005). "The Decentering of Second Wave Feminism and the Rise of the Third Wave", Science and Society, vol. 69, no.1. January: 56-91.

Marcuse, Herbert (2007). Art and Liberation, intro. Douglas Kellner. London: Routledge.

McLellan, David (1973). Karl Marx: His life and Thought. New York: Harper and Row.

McKay, Ian (2000). “The Liberal Order Framework: A Prospectus for a Reconnaissance of Canadian History", Canadian Historical Review, vol. 81, no. 3 (September): 617645.

McCaughey, Martha (2012). "Community", in Catherine M. Orr, Ann Braithwaite and Diane Lichtenstein, (eds.), Rethinking Women's and Gender Studies: 135-151. New York: Routledge.

Mills, Charles W. (1997). The Racial Contract. Ithaca: Cornell University.

Mohanty, Chandra Talpade (2003). Feminism without Borders: Decolonizing Theory: Practicing Solidarity. Durham: Duke University Press.

Morgan, Lewis H. (2004 [1887]). Ancient Society, Or Researches in the Lines of Human Progress from Savagery through Barbarism to Civilization, transcribed for www.marxist.org Ibne Hasan. First published by MacMillan and Co., London, 1877.http://www.marxists.org/reference/archive/morgan-lewis/ancient-society. 
[Accessed April 23, 2012].

Mullings, Leith (1997). On Our Own Terms: Race, Class and Gender in the Lives of African American Women. New York: Routledge.

Murphy, Kevin (2009). "Can We Write the History of the Russian Revolution? A Belated Response to Eric Hobsbawm”, Historical Materialism, vol. 15: 3-19.

Painter, Nell Irvin (1996). Sojourner Truth: A Life, A Symbol. New York: WW Norton and Co.

Peirine, Eleanor Wright (1996). Morgentaler: A Difficult Hero. New York: Random House.

Piepmeier, Alison (2012). "Beseigement", in i Catherine M. Orr, Ann Braithwaite and Diane Lichtenstein, (eds.), Rethinking Women's and Gender Studies: 119-134. New York: Routledge.

Razack, Sherene, Malinda Smith and Sunera Thobani (eds.) (2010). States of Race: Critical Race Feminism for the $21^{\text {st }}$ Century. Toronto: Between the Lines.

Rees, John (1998). "Revolutionary Marxism and Academic Marxism”, in John Rees, ed., Essays on Historical Materialism: 161-175. London: Bookmarks.

Rein, Sandra (2007). "Reading Dunayevskaya: Engaging the Emergence of Marxist Humanism, 1930-1955", Ph.D. Dissertation. Department of Political Science, University of Alberta.

Rich, Adrienne (1991). "Foreword", to Raya Dunayevskaya, Rosa Luxemburg, Women's Liberation, and Marx's Philosophy of Revolution, $2^{\text {nd }}$ ed. Chicago: University of Illinois Press, xi-xx.

Riddell, John (2010). "Clara Zetkin's Struggle for the United Front", International Socialist Review (January-February). http://www.isreview.org/issues/68/68.shtml [Accessed April 1, 2012].

Riddell, John (2011). “Communist History Debated at 'Historical Materialism” London Conference" (November 25). http://johnriddell.wordpress.com/2011/11/25/communist-history-debated-athistorical-materialism-london-conference/ [Accessed April 4, 2012]. 
Riddell, John (ed. and trans.) (2012). Toward the United Front: Proceedings of the Fourth Congress of the Communist International, 1922. Leiden: Brill.

Roberts, Adrienne (2010). "Governing Social Marginality: Towards a Feminist Political Economy of Poverty, Crime and Punishment", Doctoral Dissertation, Department of Political Science, York University (October).

Roskos, L. and Willis, P. (2007). 'Introduction to Women's Bodies, Gender Analysis, Feminist Politics at the Forum Social Mundial', Journal of International Women's Studies, vol. 8, no. 3: 1-9.

Rowbotham, Sheila (1973). Woman's Consciousness, Man's World. Harmondsworth: Penguin Books.

Sacks, Karen (1979). Sisters and Wives: The Past and Future of Sexual Equality. Wesport, Connecticut: Greenwood Press.

Said, Edward W. (1994). Representations of the Intellectual: The 1993 Reith Lectures. New York: Vintage Books, Random House Inc.

St. Denis, Verna (2007). "Feminism is for Everybody: Aboriginal Women, Feminism and Diversity", in Joyce Green (ed.), Making Space for Aboriginal Women: 33-52. Winnipeg, Manitoba: Fernwood.

Smith, Dorothy (2005). "Feminism and Marxism - A Place to Begin, A Way to Go," in Sean P. Hier, ed., Contemporary Sociological Thought: Themes and Theories: 225232. Toronto: Canadian Scholars' Press.

Stasiulis, Daiva and Abigail B. Bakan (2005). Negotiating Citizenship: Migrant Women in Canada and the Global System. Toronto ; University of Toronto Press.

Sullivan, Shannon and Nancy Tuana (eds.) (2007). Race and Epistemologies of Ignorance. New York: State University of New York.

Tomba, Massimiliano (2009). "Historical Temporalities of Capital: An Anti-Historicist Perspective", Historical Materialism, no. 17: 44-65. 
Vogel, Lise (1983). Marxism and the Oppression of Women: Toward a Unitary Theory. New Brunswick, NJ: Rutgers University Press.

Walker, Rebecca (1992). “Becoming the Third Wave”, Ms. Magazine,vol.12: 39-41.

Whitaker, Reg (2002). "What's Wrong with Canadian Universities”, Literary Review of Canada (September): 1-11. http://reviewcanada.ca/ [Accessed April 1, 2012].

Young, Iris Marion (1990). Justice and the Politics of Difference. Princeton, N.J.: Princeton University Press. 